\title{
SOLAR PHOTOVOLTAIC STATUS WORLDWIDE
}

\author{
Apoorv Sethi ${ }^{1}$, Somya Tiwari ${ }^{2}$ \\ E-Mail ID: 1apoorvsethi.btech16@ansaluniversity.edu.in,'somyatiwari@ansaluniversity.edu.in \\ ${ }^{1}$ Student, School of Engineering \& Technology, Ansal University, Gurgaon, Haryana, India \\ ${ }^{2}$ Assistant Professor, School of Engineering \& Technology, Ansal University, Gurgaon, Haryana, India
}

\begin{abstract}
Industrial development and population growth has led to a massive surge in global energy demand. Howsoever, along with rapid advances in renewable energy technology, global environmental issues are opening up new possibilities for the use of renewable energy resources. Solar Photovoltaic is the development phenomenon that generates electrical current by directly converting sunlight into electricity by photovoltaic cells (Silicon based cells, doped with other components). As the most plentiful, inexhaustible and sustainable of the renewable energy available to date, Solar Energy also poses a great factor in reliability. Solar energy cannot henceforth be used as a stand-alone source of electricity. Notwithstanding the possession of many benefits, there are some disadvantages to the introduction of this technology, the deployment costs being the biggest downside withdraws people's trust in this technology. In this context, this paper will provide a compiled analysis of the data reflecting the technological progress made in the last few years in the field of mono and polycrystalline thin film photovoltaic (PV) technologies, in addition to reference to any extra work completed. Journey of photovoltaic which started from 1954 now reached to $635 \mathrm{GW}$ in the year 2019. Every year new countries are joining the $1 \mathrm{GW}$ capacity landmark and making this journey more successful. To a very great extent, the worldwide growth of photovoltaics is dynamic and strongly varies by region. Started by William Grylls Adams in 1876 and the continuous evolution of solar photovoltaics, by the end of 2016 a massive increase came, Where the combined photovoltaic potential increased by more than $75 \mathrm{GW}$, resulting in huge output, adequate to meet 1.8 percent of the total worldwide electricity demand. Through this paper, the detailed data of the development, nation wise, and the steps taken by the countries to enhance growth over the years have been depicted to produce a well-established knowledge of the facts available on the same.
\end{abstract}

Keywords: Solar energy, solar photovoltaic, global energy, energy resources.

\section{INTRODUCTION}

Industrial development and population growth has led to a massive surge in global energy demand. Howsoever, along with rapid advances in renewable energy technology, global environmental issues are opening up new possibilities for the use of renewable energy resources. Solar Photovoltaic is the development phenomenon that generates electrical current by direct converting sunlight into electricity by photovoltaic cells (Silicon based cells, doped with other components). As the most plentiful, inexhaustible and sustainable of the renewables energy available to date, Solar Energy also poses a great factor in reliability. Solar energy cannot henceforth be used as a stand-alone source of electricity. Notwithstanding the possession of many benefits, there are some disadvantages to the introduction of this technology, the deployment costs being the biggest downside withdraws people's trust in this technology. To a very great extent, the worldwide growth of photovoltaics is dynamic and strongly varies by region. Started by William Grylls Adams in 1876 and the continuous evolution of solar photovoltaics, by the end of 2016 a massive increase came, Where the combined photovoltaic potential increased by more than $75 \mathrm{GW}$, resulting in a huge output, adequate to meet 1.8 percent of the total worldwide electricity demand. [1]

\section{DEVELOPMENT AND UTILIZATION}

\subsection{Early Day}

Development of Solar Technologies began way back in the 1860's by prediction of the upcoming scarcity of coal. Charles Fritts in 1884, built the initial photovoltaic array on the ceiling of a New York(NY) city structure, using 1 percent selenium performance cells. The development of Solar Technologies however went moribund in the early 20th century due to the growing supply of fossil fuel and its usefulness. The electricity and black gold crisis in 1973 and 1979 reinvigorated attention towards the development of solar technologies, caused due to reorganisation of energy policies. [2] The installations of solar photovoltaic systems grew expeditiously between 1970 and 1983, however due to the plummeting oil prices in early 1980's, reduced the growth of photovoltaics between 1984 to 1996.

\subsection{Further Growth}

An aggressive growth of photovoltaic technology was observed between 1992 to 2018 . As a result, to which the solar production costs decreased dramatically as automation and financial sources have increased. United States of America has been historically, the leading country in installed photovoltaics for a decade and more, by its total capacity mounting to $77 \mathrm{MW}$ as of 1996, more than any other country at that moment. Japan became the leader, starting from late 1990's until 2005, when Germany took over and entitled itself as the world leader with the production of over $40 \mathrm{GW}$ of total capacity by the year 2016. Howsoever, China surpassed Germany and all the other countries by a massive production of over $100 \mathrm{GW}$ of installed energy by the year 2017.The total established PV capacity reached an all-time high of $512 \mathrm{GW}$ approx. by the end of 2018, out of which about $35 \%$ (i.e. 180 GW) were utility-scale plants. Which indicates a $27 \%$ growth in energy since 2017 and also contributed to a 7- 
$8 \%$ domestic consumption in Chile, Germany, Greece and Italy. There are many types of solar cell are available with many different types of characteristics. [3] Whereas in the year 2019, the Global PV installations were 121 GW. Sufficient enough to supply about $3 \%$ global electricity demand. However, the Solar PV is expected to reach 4.7 TW $(4,700 \mathrm{GW})$ by 2050 . Much of the energy will be deployed in India and China, making solar photovoltaics the world's largest electricity source.

\section{CURRENT STATUS}

\subsection{Worldwide}

Average worldwide Photovoltaic growth has been estimated to be $40 \%$ amidst the period of 2000-2013, with the total installed capacity reaching $306.5 \mathrm{GW}$ by the end of 2016. Cumulative installed capacity exceeded 403GW by the start of 2018, adequate to provide 2.1 per cent of overall energy demand worldwide. [4]

\subsection{Regions}

As of 2018, Asia was the fastest growing region with nearly 75 per cent of global facilities. In 2017, China alone represented more than half the worldwide deployment. As far as cumulative capacity is concerned, Asia was the foremost developed region in 2017 with more than half the total world of $401 \mathrm{GW}$. Europe kept saying no as a percentage of the world photovoltaics market. Europe accounted for 28 per cent of world capacity in 2017, land $19 \%$ and geographic area $2 \%$.

\subsection{Countries and Territories}

Photovoltaics development is highly diverse and varies widely from country to country. The accessible solar Photovoltaic capacity in Central America, can adequately provide twelve percent of the country's strength, whereas Germany, Italy and Greece are sufficient to supply between seven to eight percent of domestic energy use respectively. The top PV deployments in 2017 were China (53 GW), the US (10.6 GW), India (9 GW) and Japan $(7 \mathrm{GW})$, the same four countries that led installations in 2016. Worldwide efforts have started for commercially for solar cell production and its improvements at very early because scope was there in the renewable sector. Table 3.1 is showing cumulative, annual new and growth in the field of solar photovoltaic year wise from 2014 to 2020.

Table-3.1 Worldwide Solar Photovoltaic Installation for Period 2014 to 2020

\begin{tabular}{|l|l|l|l|l|l|l|l|}
\hline Year end & $\mathbf{2 0 1 4}$ & $\mathbf{2 0 1 5}$ & $\mathbf{2 0 1 6}$ & $\mathbf{2 0 1 7}$ & $\mathbf{2 0 1 8}$ & $\mathbf{2 0 1 9}$ & $\mathbf{2 0 2 0}$ \\
\hline & & & & & & & \\
\hline Cumulative & 178.4 & 229.3 & 306.5 & 403.3 & 512 & 633 & $<770$ \\
\hline & & & & & & & \\
\hline Annual new & 40.1 & 50.9 & 76.8 & 99 & 109 & 121 & $121-154$ \\
\hline & & & & & & & \\
\hline Growth & $28 \%$ & $29 \%$ & $32 \%$ & $34 \%$ & $27 \%$ & $24 \%$ & \\
\hline
\end{tabular}

\subsection{Solar Power India}

India boasts being one of the top growing Photovoltaic energy system. India itself produced more than 9,000 MW of documented energy in 2017 adding an additional 9,600 MW of solar energy expansion Photovoltaic-projects. India began a Solar Project in 2010, covered by the country's Plan of Action on Global Climate Change, which aims to cross $20 \mathrm{GW}$ by 2022.This goal was achieved in January 2018 with India reaching $20 \mathrm{GW}$ of installed solar power four years before its deadline. Indian Prime Minister Narendra Modi announced an initiative in January 2015 Increasing Photovoltaic power to a massive $100 \mathrm{GW}$ and the cumulative energy renewable up to $175 \mathrm{GW}$ by the year 2022. This goal is unrealistic in view of the $177 \mathrm{GW}$ worldwide Photovoltaic capacity at that very point, India having only $2.5 \mathrm{GW}$ 's mounted. Some wide Photovoltaic mesh's are in service, some of which are included in the largest in the world, for example Ultra Mega Solar Park in Kurnool, carrying 1,000 MW of energy, Kamuthi Solar Project carrying 648 MW, Charanka Photovoltaic Park carrying 345 MW, Bhadla Photovoltaic Park presently carrying $480 \mathrm{MW}$ with a proposed Power of 2,255 MW and a combination of 605 MW Gujarat Photovoltaic Parks. Railways in India, enrolled solar working trains in July 2017. [5] Lights, fans and displays inside the coaches are powered through solar panels. Cochin International Airport is the $1^{\text {st }}$ on the globe to fly solely on Photovoltaic energy, managing a thousand plus flights a week. The Republic likewise Diu region is completely go past solar energy. This scheme weans farmers away from usage of diesel-powered pumps and help them generate an extra income for them. It's one of the innovative ways in which the govt. is empowering the agricultural population with the assistance of alternative energy by addressing specific issues like water availability. In the year 2012, Globally, the $1^{\text {st }}$ ever Photovoltaic channel-top project was constructed in Gujarat. For networking walk in areas isolated and unavailable, govt. supplies 200 to 300 (Wp) solar energy packs along with accumulator packs containing five Light Emitting Diodes, one Direct Current ventilator and one Direct Current control socket. Other services like Photovoltaic Road Lamp's network, providing solar D C lamps, gas lamps etc. Hon'ble PM of India, Narendra Modi, and François Hollande, former President of France, then laid the stone of the muse for the headquarters of International Solar Association (ISA) at Gwalpahari, India. ISA is committed to the promotion and expansion of renewable energy and raising the cost of Output and growth through greater deployment in developing countries of solar technologies. [6][7][8] On June $30^{\text {th }} 2016$, the union set foot 
into a collaboration with the World Bank to accelerate the assembling of alternative energy financing, to achieve the objectives of large-scale, sustainable alternative energy implication worldwide. At the World Forum on Futuristic Power, held in United Arab Emirate's capital in January 2018, the govt. of India announced the putting in Development of a 350-million-dollar solar energy fund to finance solar ventures. During the plenary speech at the 2018 World Economic Forum in Davos, Prime Minister Narendra Modi advocated renewable energy and welcomed investments within the Indian sector to Make business easy The optimistic strategy Modi unveiled in the run-up to the climatic held in France, obtained a great deal of questioning and the attempt of the government to raise conventional energy by focusing on open energy The price reduction bid was deemed ineffective. Beginning around 2016-2017, it was penned out, the production of fresh conventional energies was cheap in comparison to the traditional non-conventional ones in India. [9]

\section{FUTURE ASPECTS}

The future of energy primarily takes into account the two well-known types of energy conversion techniques, Photovoltaic electricity (PV) and Focused Photovoltaic Power(CSP). [10] Due to the fact that energy supply facilities generally last for several decades, technologies in these categories will dominate solar-powered generation between the present and the year 2050, which we don't try to look beyond that date. In contrast to some earlier way forward for studies, we also present no forecasts for 2 reasons. Firstly, the dramatic expansion of solar industry from its comparatively minor current scale may produce changes we don't pretend to be ready to foresee today. Secondly, we recognize the future solar deployment shall solely depend upon uncertain future market conditions and public policies including policies geared toward mitigating global activity. As in other studies during this series, our primary aim is to tell decision-makers within the developed world, particularly the US. We consider the employment of grid-connected solar-powered generators to switch conventional sources of electricity. [11] For the over one billion people within the developing world who lack access to a reliable electric grid, the worth of small-scale PV generation is usually outweighed by the enormous value of access to electricity. Additionally, certain evolving countries, utilize Photovoltaic energy, making it economical to cut back reliance on imported oil, particularly if that oil must be moved by truck to remote generator sites.

\subsection{Improvement in photovoltaic energy and capacity lead to enhanced outlook}

Photovoltaic power's greatest downside is that it only operates for a portion of the day. A 2012 estimated that greater the number of photovoltaic panels installed, the lesser the power would be because all the power would be produced without delay and other energy production methods would still be needed in the night. A study conducted in 2016, came to a conclusion that the downfall in the energy production will reduce solar output, unless the Volume of storage increases significantly [12].

\subsection{The sun setting on Traditional Resources}

Relying on the massive decline in Photovoltaic prices in the, Non-Conventional Tanks have become more and less competitive, particularly during peak solar production. As such, at present, reduction in current plants' sales and productivity, which could be expected to find yourself retired. As the sun begins to line up, however, solar generation Declines, generating a need to rapidly develop non-conventional sources of generation to meet the needs of power past sunset. [13] Power storing methods, however, are getting old and allowing removable Photovoltaic storage assets to tackle variable renewable energy challenges. Moreover, over the previous couple of years, the value of energy storage has greatly decreased. It has allowed more sophisticated solar plus storage systems to occur.

\subsection{Transformation of neat power generation methods}

The environment has shown signs of an ultimatum, which requires an action to be taken rapidly. Conventional sources are very-often considered a serious part of the global climatic reshape response, which not only have high availability at present, but prices are in comparison to similar sources and are predicted to decline into the longer term. Such profitable advantages to health-care are derived from the transfer to conventional energy generation, that are additional to the established benefits of the power sector and hence the environment. The power industry is at the crossroads of extraordinary business activities, at a time when the environment, climate and public-health are all working intensively to find solutions to systemic problems within each. Renewables are assured of delivering by eager and capable technologies. The solar industry is moving ahead, but markets and regulations must remain in place to allow the transition to scrub energy into the future.

\subsection{Effect of Coronavirus pandemic on the renewable energy industry}

The Chinese coronavirus crisis is most-likely to have far reaching aftermath around the globe as industrialmanufacturing has stalled completely. Amidst diverse sectors that probably feel this spread of disease is that of the solar energy sector. India is amongst world's fastest growing Photovoltaic power markets and manufacturer's experience several-month delays in delivering plant equipment. Multiple developers are suggested to news media that they need to be warned of delaying that could prevent project undertaking as India aims to reach a target of 1 quintal gigawatts of installed Photovoltaic energy storage by December 2022. The nation had 34 gigawatts of installed capacity at the tip of 2019, leaving a gap of 66 gigawatts to be filled in 36 months. Most Chinese solar equipment manufacturers have yet to reopen facilities at the extended twelve month break over Lunar, according to multiple international news sources. Similar to several major markets in solar energy, India is very dependent on Chinese products. A PV Magazine survey showed that China accounted for 78 per cent of all solar cells and 
modules imported into India.[14] [15] But China remains a highly dominant manufacturer of solar cells and modules, despite the Indian Government's safeguard duty. Prior to the in situ safeguard duty, China's share of Indian imports was over 90 per cent. Many analysts say that manufacturing slowdowns are only one of many possible delays across the entire supply chain. Increased screening could similarly delay shipments at ports. Delays in shipping are not the only possible developmental headache. Long-term shutdown of production facilities, can drive raw materials and modules prices, affecting project financial aspects. The developers are required to present the govt for a few reliefs in this time of crisis.

\section{REFERENCES}

[1] Jäger-Waldau, A. (2020). Snapshot of Photovoltaics-February 2020. Energies, 13(4), 930.

[2] https://theenergychoices.blogspot.com/2017/10/where-is-solar-energy-used-most.html

[3] Ullal, H. S., Zwelbel, K., \& Von Roedern, B. (1997, September). Current status of polycrystalline thin-film PV technologies. In Conference Record of the Twenty Sixth IEEE Photovoltaic Specialists Conference-1997 (pp. 301-305). IEEE.

[4] Hosenuzzaman, M., Rahim, N. A., Selvaraj, J., Hasanuzzaman, M., Malek, A. A., \& Nahar, A. (2015). Global prospects, progress, policies, and environmental impact of solar photovoltaic power generation. Renewable and Sustainable Energy Reviews, 41, 284-297.

[5] Malinowski, M., Leon, J. I., \& Abu-Rub, H. (2017). Solar photovoltaic and thermal energy systems: Current technology and future trends. Proceedings of the IEEE, 105(11), 2132-2146

[6] https://solarenergycanada.org/will-solar-energy-be-used-in-the-future

[7] http://www.academia.edu/Documents/in/Solar_PV

[8] Kumar, N. M., Dasari, S., \& Reddy, J. B. (2018). Availability factor of a PV power plant: evaluation based on generation and inverter running periods. Energy Procedia, 147, 71-77

[9] https://www.mdpi.com/1996-1073/12/7/1213/pdf

[10] Perez, R., Letendre, S., \& Herig, C. (2001). PV and grid reliability: availability of PV power during capacity shortfalls. In FORUM-PROCEEDINGS- (pp. 49-54). AMERICAN SOLAR ENERGY SOC \& THE AMERICAN INSTITUTE OF ARCHITECTS.

[11] Tyagi, V. V., Rahim, N. A., Rahim, N. A., Jeyraj, A., \& Selvaraj, L. (2013). Progress in solar PV technology: Research and achievement. Renewable and sustainable energy reviews, 20, 443-461

[12] Borenstein, S. (2017). Private net benefits of residential solar PV: The role of electricity tariffs, tax incentives, and rebates. Journal of the Association of Environmental and Resource Economists, 4(S1), S85S122.

[13] https://www.renewableenergyworld.com/2019/

[14] https://cleantechnica.com/2020/02/17/coronavirus-outbreak-could-hit-indias-solar-growth/

[15] https://www.irena.org//media/Files/IRENA/Agency/Publication/2019/Nov/IRENA_Future_of_Solar_PV_2 019.pdf 